\title{
Afrikaner Christianity and the concePt of eMPIRE
}

Author:

Erna Oliver ${ }^{1}$

\section{Affiliation:}

${ }^{1}$ Department of Christian Spirituality, Church History and Missiology, University of South Africa, South Africa

\section{Correspondence to:}

Erna Oliver

email:

unut2@unisa.ac.za

Postal address:

PO Box 31235, Totiusdal

0134, South Africa

\section{Keywords:}

Afrikaners; Christian faith empire; South African history; Traditional

Afrikaans-speaking churches

\section{Dates:}

Received: 28 Apr. 2010

Accepted: 10 June 2010

Published: 03 Aug. 2010

How to cite this article: Oliver, E., 2010, 'Afrikaner Christianity and the concept of empire ', Verbum et Ecclesia 31(1), Art. \#393, 7 pages. DOI: 10.4102 ve.v31i1.393

\section{This article is available} at:

http://www.ve.org.za

\section{Note:}

Mission and empire in the history of Christianity was the theme of the bi-annual spring meeting of the American Society of Church History that was held in Montreal, Canada on 16-18 April 2009. An earlier edition of this paper, titled Mission and empire in the history of Christianity in South Africa: Is Christianity to blame?, was read at the conference.

\section{(C) 2010. The Authors.} Licensee: OpenJournals Publishing. This work is licensed under the

Creative Commons

Attribution License.

\begin{abstract}
Not many Protestant countries in the world have been as influenced by faith as South Africa. Although South Africa was never officially a Christian country, politics, economic development, social life and the culture of the 'rainbow nation' was either moulded on, or influenced by, the Calvinistic Christianity that came to the country along with the European merchants. The privileged position of Christianity ended in 1994 when South Africa became a neutral state with guaranteed religious freedom for all.

Although more than 80 per cent of the population claim that they are Christians, it seems as if the word is not meant any more as a religion with a value system and moral obligations, but only as a convenient label. The reason behind the contrast between theory and practice must be investigated. One possible reason could be found in the traditional Afrikaans-speaking churches' participation of, and contribution to, the 'empire' concept. The responsibility of the individual to practise his or her faith was taken over by the power of the state and church.
\end{abstract}

\section{INTRODUCTION}

Although South Africa was never officially known as a Christian country, the 2001 census showed that approximately 80 per cent of the South African population regarded itself as Christians, while about 5 per cent indicated that they belong to religions such as Islam, Hinduism and Judaism (Census 2001:31). Thus, about 85 per cent of the South African population adheres to religions that forbid participation in criminal and unethical behaviour. In theory then, South Africans should be able to live normal, creative lives in a country where the rainbow nation, guided by, amongst other things, the moral foundations of faith, lives and works peacefully together aiming to improve the quality of life for everyone.

However, day-to-day living in our country is not for the fainthearted. According to Nationmaster statistics, South Africa tops the list of countries worldwide when it comes to per capita assaults, AIDS deaths, gun violence, homicide and rape. South Africa is fourth on the list for robberies and drug offences and tenth for burglaries and the total number of crimes committed (Nationmaster 2009). Nearly half of the population lives in poverty and more than a quarter of the people are unemployed (Statistics South Africa 2004).

The contrast between the anticipated perception regarding the influence of religion and the actual living conditions in South Africa is an issue of great concern to some Christians. The widening gap between 'official' faith and day-to-day practices (Denise Ackermann says: 'I have never heard a sermon on rape' [Camp 1994:165]), forced an investigation on a possible explanation for the current problematic situation of marginalisation of the doctrine of sin (cf. Conradi 2005) amid skyrocketing crime rates. Why are the large Christian population not able to act as a stabilising influence in our society?

The focus of this study is on the three traditional Afrikaans-speaking churches and their particular strain of Reformed, Calvinistic faith. Their lack of influence on society became more evident with each passing year since 1994. Why do Christian principles fail to guide the behaviour of Afrikaansspeaking Christians? Why did the new freedom of living with no boundaries (freedoms, such as who to marry, where to live, or whether or not to have an abortion) convert into a mindset of living without laws (for instance, disregarding traffic rules and increasing road rage)?

Both before and during the apartheid era, the church had great power and a huge influence on people. Religious institutions were vital and represented a powerful media of communication, having access to an impressive audience and exercising a certain traditional authority. When the democratic process started during the last decade of the previous century, Assabi noted: 'In this capacity alone, there is already a definite role for religion in the reconstruction of society' (Assabi 1991:77). But in practice, this never crystallised and the question remains: Why not?

We are far more conditioned by our past than we can hope to understand. Many of our present crises (be they economic, socio-political or the daily trauma of violence and conflict) are the fruit of a historical harvest; a confirmation of the truism that, in spite of the good intentions of the harvesters, one can only reap what one sows.

(Pillay 1991:1)

Is it possible, in light of Pillay's words, to name the marriage between Afrikaner Christianity and the virtual Afrikaner Empire as a major contributing factor to the current contradiction between what we confess and what we do? According to Rieger (2007:12), when we find ourselves at the intersection between theology and empire, we face two tasks: one is analytical and the other is constructive. This study will be analytical and selective. Botha, in his inaugural lecture (Unisa 2009), asked: 'Can Christianity be saved from Empire?' He identified three clusters of theological responses towards the anti-imperialistic theological discourse. 
This study corresponds with his question on how to get the Christian faith from the grip of the virtual empire. After introducing the concept of empire, the different historical empires that influenced and controlled the country need to be briefly identified. This is done by a few large brush strokes as this sets the scene for the development of the virtual Afrikaner Empire. These empires used the same focus areas that Alejandro Colas, a lecturer in International Relations at the University of London, identified, and which were also used later by the Afrikaners. A few short notes on the unique characteristics of Afrikaner Christianity provide a background for understanding the relationship that later developed between empire and religion. Using the key dimensions of empire, examples will be used to explain how Christianity was manipulated to create and maintain the Afrikaner Empire. Institutional control of faith proved extremely costly to Christianity. In the first place, it caused the Christian faith to lose its credibility and influence on society. It also disempowered individuals and currently, after losing its power and credibility, the institution is not able to reverse the process by empowering Christians to make a difference in society.

\section{THE CONCEPT OF EMPIRE}

The intimate relation between politics and religion in South African history pulled the concept of 'empire' into the equation of the investigation (cf. Botha 2009; Nelson-Pallmeyer 2005). There are many definitions for this word and they are constantly contested and reaffirmed with reference to the past (Colas 2007:3). Colas, says that 'Empire is above all a study of specific expressions of power' (Colas 2007:158, emphasis added). Rieger (2007:4) expands on this and defines empire as massive concentrations of power, which permeate all aspects of life and which cannot be controlled by any one factor alone. This power takes various different shapes and forms with the major distinction between virtual and actual empires as state or political entities.

South African history shows that empires do not function only on an international, historical level, like the Dutch colony that was started to provide fresh food and water for the merchantmen on their way to and from the East, or the British invasion of the country nearly a hundred and fifty years later, but also on the virtual level of the Afrikaner empire that developed during the 20th century.

Colas identifies three important dimensions that are common to most historical empires. First of all, empires are built on expansion; conquering other peoples and territories, often settling among them, and usually absorbing them through a combination of coercive, legal, cultural and economical mechanisms into a larger socio-economical and political entity - an empire (Colas 2007:6). The policy and process, guided in large measure by an ideologically constructed sense of superiority, seeks to assimilate foreign regions and populations into an expanding polity. This incorporation needs not be territorial or juridical (Colas 2007:7).

Secondly, he claims that empires are hierarchical in nature by expanding social formations, proclaimed and generally enforcing their political, cultural and military superiority by codifying the subordination of subject peoples, thereby leaving no doubts as to where power and authority reside, ruling from the metropolitan centre or motherland along geographical lines of super- and subordination (Colas 2007:7). Empires normally have capitals that concentrate the institutions of imperial power and wealth and thereby aim to command diverse and distant populations from a geographical centre. In many cases, such capitals become imperial microcosms, displaying in their customs, demography, architecture and markets the wealth of empire. Similarly, imperial outposts bear the imprint of their peripheral status (like the renaming of places). The way of life
- from work patterns and the practice of the law to recreation and the way people dress in their every day existence - is also controlled by the empire (Colas 2007:8).

Thirdly, the empire provides 'order' to its subjects. Imperial order refers to the condition of stability, legitimate authority and a sense of belonging that provides security for the local population. Public infrastructure, the law, the lingua franca, shared cultural-religious institutions and customs, common currencies, and imperial armies, navies and constabularies all propped up imperial orders. The reproduction of a vast and disparate polity over an extended period of time requires the allegiance, or at least acquiescence of its subjects. It usually involves use of force against other peoples and polities - be they imperial rivals or conquered subjects as war and violence are intrinsic to imperial rule (Colas 2007:9). Such orders have been periodically challenged by forces of 'disorder' - revolts, invasions, migrations, occupations, civil wars and internecine conflict - many of which presaged or sealed a terminal decline of imperial rule (Pui-lan, Compier \& Rieger 2007:9).

Colas based his theory regarding empire on the results of unequal relations regarding space, market, and culture. At first glance, it seems as if these issues are not related to Christianity, but the tertium comparationis between empire and Christianity lies in the statement by Colas that unlike states that control territory, empires control people (Colas 2007:9). Both the three key dimensions of empire explained above, as well as the issues of space, market and culture could be linked to the control of people by the Afrikaans-speaking churches in their link to power-sharing with the apartheid government.

\section{HISTORICAL EMPIRES IN SOUTH AFRICA}

\section{The market-driven Dutch Empire}

The Cape was colonised by the Dutch East India Company (DEIC) in 1652, a company which was not exclusive in recruiting its servants (Le May 1995:3). Among the settlers were people from Sweden, Germany, Scandinavia, Flanders and France (Preston 1989:15). These colonists used their faith as a political identity, calling themselves Christians in order to distinguish them from both the indigenous population and the slaves (Giliomee 2003:41). The DEIC exercised authority over the church in an Erastian manner by advocating the doctrine of state supremacy in all ecclesiastical affairs (Gerstner 1991:187). Attendance of all sermons was compulsory and stern laws existed to punish those who did not comply (Jooste 1946:242). Ministers of religion, comforters of the sick and school teachers were all employees of the DEIC and all had to adhere to the Three Forms of Unity. This linked the government, church and education into a tight partnership, with the government taking the responsibility to ensure that the people adhere to Christian values and laws.

Outside of the DEIC, the free burghers pioneered the nation building process of the Afrikaners with the Bible as their main tool. History has shown that Calvinists, more than any other, are comfortable in God's Word. They practised the instructions from the Bible in their lives and the doctrine had a major influence on the forming of the nation (O'Kulis 1918:27). The State's edition of the Bible that was used by the colonists also contained clarifying marginal comments by the translators, the Belgic Confession and the Heidelberg Catechism, the sacramental formulas and formula prayers, as well as the songs sung by church members (Gerstner 1991:111). Large portions of Scripture, the lyrics of the songs and the complete contents of the Catechism were known by heart by most of the people, as a result of the Pietistic influence (cf. Hofmeyr 1991). The Bible not only served as the family guide to life itself, it also formed the general frame of reference, both as reading material and educational tool, penetrating the thoughts, language, and actions of every Afrikaner (O'Kulis 1918:61). 'The Cape 
Dutchman, or Boer, as we call him, is a slow, good-humoured person, not given to politics, occupied much with his religion and his private affairs...' (Froude 1886:35). The Afrikaner could speak a word, in favour or against, on world and local politics, economy, literature, arts, education, and the private lives of public figures (cf. De Kiewiet 1941:17). The fact that others (like the press) made fun of the manner in which Bible texts were used with reference to politics for example, did not stop Afrikaners from using the Bible in this way (Dreyer 1977:40).

The key focus of the DEIC in terms of empire was on market and economic prosperity. This caused the Afrikaner free burghers to see themselves as underdogs, being exploited by the government (Akenson 1992:68; Giliomee 2003:23-26). With the help of the family Bible, they built for themselves a cultural and spacial identity - these issues were neglected by the DEIC Empire.

\section{The cultural and spatial-driven British and Zulu Empires}

When the British took over from the Dutch at the end of the 18th century, the focus of the ruling empire shifted to space and culture (Lambert \& Lester 2006) with their attempts to create a legacy of British citizenship. This focus brought the English into direct conflict with the Afrikaner lifestyle. By 1795, the Afrikaner identity was strong enough to resist the British attempt to turn them into English citizens (Akenson 1992:62; Pont 1970:12).

When the Voortrekkers proclaimed their republics in the northern parts of the country, the link between state and church was kept intact as ministers of religion were on the government payroll until the failed attempt of church reconciliation in 1886 (Pont 1970:36).

The conflict regarding culture and space between the British Empire and the Afrikaner nation reached its culminating point in the two Anglo-Boer Wars during the last part of the 19th century. Once again, the Afrikaners felt they were exploited and the concentration camps left a bitterness that led to the rebellion when the First World War broke out and Britain expected the Afrikaners to fight on their side against the Germans of German West Africa.

Setbacks like the Spanish flu of 1918, the depression of 1929, the drought of 1933, the floods of 1936, the poor White crisis and the Second World War, all contributed to the deepening feeling by Afrikaners that they could not seem to get a fair deal in life. The British occupation of the country ended in 1961 when South Africa became a republic.

For the sake of completeness, another empire must also be mentioned. Simultaneously with the British invasion of the Cape, an empire was created in the interior and eastern parts of the country under Shaka, the Zulu king, also focusing on space and culture. This empire was crushed by the Afrikaners moving into the interior of the country in an attempt to free themselves from the British influence.

Since 1652, South Africa was part of an empire: the first one and a half century under the economic-driven Dutch company and the next one and a half century under the spatial and cultural driven British Empire. It is not strange then, that the Afrikaners, when they came into power, followed trends form these examples in the governing of the country. What is strange and problematic, however, is the fact that the conservative Reformed Christian faith of the Afrikaner, which was so vital during the formation period of the nation and which also served as guard against the onslaught of British imperialism, lost its influence and guiding ability. This happened when the institution took religious power and responsibility from the hands of individuals.

\section{AFRIKANER CHRISTIANITY}

Calvinism, a type of reformed theology within the Christian faith, is the theological system of thought initiated by the French Reformer John Calvin (1509-1564). However, one must be careful not to equate Calvin's own view and perspective with those of later Calvinists (Compier 2007:216). South Africans who generally see themselves as Calvinists, in particular reached their own conclusions on issues such as doctrine, morals and church government. Shaped by their own unique circumstances and living conditions, they developed a unique strand of Reformed religion. While they held Calvin in special regard, Reformed ideas also came to South Africa through the works of the Continuing Reformation or Dutch Pietism (Gerstner 1991:258). One of the most significant characteristics of the Reformed tradition was its aim to bring theology down to the popular level (Gerstner 1991:114). The Dutch Reformed tradition excelled in this area with books on the level of general readers that followed the basic loci of systematic theology. Together with the Bible, the theological house books greatly influenced the thoughts and actions of the colonists (Gerstner 1991:115)

The heavy emphasis on catechesis and the theological content therein became hallmarks of the Dutch Reformed tradition. It was noted for its distinctive understanding of Christian doctrine. 'Doctrine was seen as speaking to the whole man in the totality of his existence' (Cameron 2007). The impact on the South African community was obvious:

The manners and habits of the Dutch have an extraordinary similarity from one extremity of the colony to the other. They seem indeed to be all fashioned after one model; and few individual peculiarities are to be found in one character that may not be possessed in a greater or smaller degree in another.

(Moodie 1835:146-147)

Salvation is found only in and through Jesus Christ to the exclusion of all other religions or beliefs. Christ must be believed in and explicitly confessed in order for a person to qualify for salvation (Grenz, Guretzki \& Nordling 1999:49). In the South African religious context, it means that only the Dutch Calvinistic religion was tolerated during the first 143 years after colonialisation (Jooste 1946:42). Other denominations were simply absorbed by the Reformed faith (Gerstner 1991:42). Because of this, Meyer (1940:27) claimed that Afrikaners are the only people that were born a Calvinistic nation. The Afrikaners shared amongst other things an ox wagon trek, civil war, war against empires, war with indigenous people and a gold rush with other countries that also formed during the same period in other parts of the world (such as Australia and North America). But unlike these nations, there were no public saloons, bar girls and Wild West shooting in the streets of South Africa due to the influence of the conservative faith of the nation (Meyer 1940).

However, schism and internal power struggles by individuals, as well as political and dogmatic differences severely handicapped the official Afrikaner church and its message (Schutte 1943:30). In the Zuid-Afrikaansche Republiek within one country and one nation, three different churches, all based on the Calvinistic principles, were formed within less than three decades (Oliver 2005:83). This disunity caused many problems in all aspects of life and divided the people into fanatic faith groups willing to fight against each other to prove themselves right (cf. Pont 1968:197). 'In the Transvaal, the remaining decades of the century were occupied by inter-Church bickering and abortive reconciliation' (Patterson 1957:187).

The unique aspects of Afrikaner Christianity are a study field of its own. The few remarks dotted here, serves only to portray the complexity of Afrikaner faith. On the one hand, the nation developed and was safe-guarded by practising their faith, but the picture painted by the official Afrikaner churches, on the other hand, is dark and this could provide a link to get answers 
to the initial question regarding a Christian nation that lived and died by their faith for more than three hundred years, but cannot seem to find a stabilising grip to face current challenges through faith.

\section{VIRTUAL EMPIRE AND CHRISTIANITY}

Nelson-Pallmeyer (2005:129) said that all Christianity had to do to become a servant to empire was to stress certain Biblical themes over others and to interpret and apply them on behalf of imperial objectives. The pages of the Bible are packed with religious justifications of potential building blocks for empire (Nelson-Pallmeyer 2005:120). Biblical concepts such as election and covenant were given a national, racial and cultural interpretation (Akenson 1992; Meyer 1940:110; Richardson 2001:4). The Afrikaners' excellent knowledge of the Bible became a handy tool in the hands of the government to guarantee submission to authority and to create a sense of belonging with the aid of familiar Christian symbols, laws and customs with which the people could identify and which they would be willing to defend with their lives in the Bush War that lasted for 23 of the 33 years that apartheid officially existed.

The Afrikaner government used the pillars on which empires are built to create their own virtual empire. A few short examples will serve to show how both the focus areas of an empire (market and economy as well as space and culture) were incorporated into the three main dimensions with which the Afrikaner Empire was established.

\section{Expansion}

Carrying forward the ways in which church and state were bound together from the time of the DEIC, daily government procedures were opened and closed with Christian prayers (Coetzee 1945:369). This created the impression that government actions were in line with God's will. One of the most important issues that needed to be addressed by the government after 1910 was to provide enough space for the Afrikaner to develop and get rid of the 'underdog' tag. The Dutch Reformed Church provided Biblical grounding for the Acts that were implemented to aid this process (NG Kerk report 1976), with which the other two traditional Afrikaans-speaking churches agreed. The Group Areas Act, along with all the other Acts that fitted under this cover, provided, for the first time (in most Afrikaner minds), enough space for the Afrikaner to develop and prosper.

Christian moral codes were converted into laws that enhanced Christianity and Afrikaner culture. Mixed marriages and polygamous, as well as potentially polygamous, marriages were outlawed. Muslims, Hindus and Black people that married according to their traditional customs were excluded from juridical help and support in matters such as divorce and child support. Witnesses in court cases were asked to take a Christian oath to tell the truth, regardless of the religion or belief system of the witnesses (cf. Hofmeyr 1913:3).

Another example of cultural expansion by the Afrikaner Empire was the Christian-based education through Afrikaans as the official language in almost all government schools (Cross 1999:13; Van der Kooi 1999) (only the mainly English-speaking Natal Province was excluded from the Act -Giliomee 2003:490). Even after the bloody riots of 1976 regarding Afrikaans Christian education to non-Afrikaans-speaking, non-Christian learners, there was no strong reaction from the Afrikaner churches on this issue, as they believed that this was a good way of spreading the gospel to all citizens: a man is made not by what he knows or by what he owns, but by what he believes (Geyser 1980:23). Thus, by controlling the contents of educational material, the Afrikaners attempted to change the identity of non-Afrikaners.
Sadly, these things created a huge gap between the Afrikaners and other groups. People felt that the Afrikaners saw themselves and their religion as superior. In the eyes of nonChristians, the Christian religion became a stick to punish and force them to comply with rules and laws that were not part of their culture or religions. The Afrikaners, however, found security in the familiar Christian norms and symbols and the fact that the government ensured that all adhere to 'Christian' laws. Afrikaners misinterpret this and start placing the responsibility of ensuring that people live according to their faith on the shoulders of the institutionalised church and government.

\section{Hierarchical structure}

In structuring the lives of the people, the Afrikaner Empire used a hierarchical system of controlling public opinion. The Afrikaans-speaking churches use hierarchical structures of church government, inherited from John Calvin's theology. Each church also has its geographical centre where the central church offices and the training facilities are located. The influence of these three churches, both on government and the Afrikaner nation, was according to their size. The top structure of the Dutch Reformed Church (NGK) that was the largest Afrikaans-speaking church was used to legalise government policies. Nearly all officials of the governing party of the nation counted it as their church (Richardson 2001:1).

Laws were passed to regulate the economy and market system of the country. Here, too, one can see the emphasis on creating favourable conditions for Afrikaner Christians. Laws that regulated business hours and the selling of liquor as well as the banning of business, sport and all forms of entertainment on Sundays (Sooka 1993:86) were ways in which the government tried to use the Christian faith to ensure that non-Christians fit into the chosen economic system. The most important Christian days of celebration (like Christmas, Passover and Ascension) were observed as public holidays (cf. Rosslee 1955:16-22). The Day of the Vow was also a public holiday and in troubled times, such as droughts, the government, in association with the Christian churches, would announce national days of prayer.

The Afrikaans-speaking churches expanded on their own terms. All of them decided not to incorporate believers from different race or language groups into the main structure of their churches, but to develop 'daughter' churches to accommodate these people. There were strict guidelines within which these daughter churches were to operate and hierarchically they stood under supervision of the white mother churches. Normally, the pastors and ministers from the daughter churches were not regarded as equal to those of the mother churches, both in education and status. In this regard, we must keep in mind that the Afrikaners followed the example of the practices that they were used to, both under the Dutch and the British. After settlement, the church at the Cape was not regarded as autonomous but functioned under the supervision of the Classis of Amsterdam of the Dutch Reformed Church. The British way of subjecting everything to 'home' carried this example further (Akenson 1992:62). The drastic shift in theology by the daughter churches during the 20th century alienated the mother and daughter churches from each other to such an extent that, currently, it looks as if there will not be a united Christian church in the near, or even not so near, future in South Africa.

On the cultural front, the Afrikaners' ideologically structured sense of superiority tried to reform African customs and traditions and religions into a subdued Christianity: the Afrikaner churches followed the practices of most missionaries in Africa by giving so-called 'Christian names' to African converts resulting in most Black people having two names, one traditional and one Christian. Although it was probably never the intention to degrade people with this action, it was 
definitely experienced this way by the Black population and it caused revolts during the last part of the 20th century all over Africa (Swaraj Foundation 2001). Together with the revolt against the 'second' names for Black people, the naming of places became a major political issue in the new South Africa.

The naming and renaming of places was not seen as a controversial act by the Afrikaners. They simply saw it as their right to name and rename places. In the pioneering days, the maps at the back of the family Bible were transferred to the South African landscape and Biblical names were applied whenever there was a resemblance to the eye or circumstances (e.g. Mara, Eden, Bethlehem, Nebo, Abel and Jordan or Nile). The writer Lawrence Green says that you will find the most places with biblical names outside of Palestine, in South Africa (Jordaan 2004:90). The democratic government changed the names of some places back to their traditional names and this caused great anxiety amongst some Afrikaners who see this as an attack on their religion or culture (depending on the names that are changed).

Some laws that were passed restricted historical and cultural expressions. Although Christians believe in miracle healings in the name of Jesus Christ, they also put a high value on modern Western medical science and technology. Therefore, the practice of Western medicine was allowed and underwritten by medical schemes, but traditional medication (of all the different cultures, including the traditional field medicine of the Afrikaners called Boererate) was not officially recognised.

The most extreme form of hierarchy during the Apartheid Empire was racism, supported by the Afrikaans-speaking churches (South Africa 1950:cols. 4141-4142). The Population Registration Act of 1950 served as the foundation for a superstructure of laws that entrenched racial divisions (Richardson 2001:4). Work patterns and job reservations formed part of the hierarchically imposed life under apartheid. The NGK led the attempts to justify racial separation on a Biblical and theological basis (NG Kerk 1975:100) resulting in the 'cultural and ideological tail wagging the theological dog' (Richardson 2001:5).

\section{Order}

The fact that Afrikaners were generally religious and held great respect both for the church as institution and its officials, played into the hands of the apartheid government to provide order and stability regarding cultural and economical aspects during its reign. By controlling the public opinion on issues such as abortion, divorce, suicide, and the death penalty, the government exercised a firm grip on society by simply implementing 'Christian' values as laws and rules.

National symbols (cf. Oliver 2008:314) can be seen as exhibitions of the character of a nation. Such symbols can be found on money, weapons, logos, medals, flags, monuments, structures, stamps and even people that became national icons (Jenkins 2004:1). The national motto was copied and later translated from the Dutch Bible (Pama 1960:5). The national anthems (Oliver 2008:315), including the anthems of the Boer Republics and the national anthem of the apartheid regime, as well as the current anthem, praise God as almighty ruler over all on earth (ANC 1996).

The smallest South African coin (1 cent) bore the image of two sparrows (Mt 10:29) to remind the people of the constant care of the Lord (Nel 2002). South Africa was the only country in the world that had sparrows on its money. It changed in 2000 when the small change was discontinued. The R1 coin still have the words 'all the Glory to God' printed in Latin on it.

Normally, the first building that was erected where towns later developed was a Christian church (Stuart 1854:13). Examples of towns with big church squares in the town centre are found all over the country (Bryce 1900:320). Pretoria and Potchefstroom are excellent examples. This, however, is not true of the towns that developed due to the gold rush and diamond rush. Here, we can refer to towns like Pilgrims Rest and Johannesburg as examples (Coetzee 1945:422). The altar form of the Voortrekker monument in Pretoria (Pretorius 2008) emphasises the impact that the Old Testament had on the lives of the people (Akenson 1992:61; Calpin 1944:17; Rose 1902:10, 11).

Traditionally, Christians do not tolerate gambling (cf. Van Wyk 1980), but in the South African history, gambling was allowed on government terms and under cover. Horse racing and betting were allowed and, during the Bush War, Bonus Obligations were sold to help fund the military expenses. During the apartheid regime, casinos operated just outside national borders in the socalled 'homelands'. So, on the one hand, Christian values were upheld, but on the other hand, ways around it were provided by the same people who claimed to preserve Christianity: the government and the official churches.

The Afrikaner government, which consisted of Christian Afrikaner men, used their religious convictions to, in their view, be obedient to God in creating a society where his Word and his will acted as law. Surely, most of these men acted not with the intention of building an earthy empire, but to the contrary, thought and believed that they were supporting the expansion of God's kingdom. However, by allowing the church to take the responsibility of acting according to one's faith out of the hands of individuals, the harm done to Christianity in general in South Africa cannot easily be undone.

The phenomenal charity work that Christian churches and semi-Church organisations are doing with the aid of voluntary workers, serve to paint the only positive aspect of Afrikaner Christian influence on society (Symington 2005). Child care, counselling, patient care, dealing with unwanted pregnancies, as well as care for the aged, disabled, addicts, HIV/AIDS patients, orphans, convicts and street children (NG Kerk 2006) are all, to a large extent, in the hands of Afrikaner Christian voluntary workers. This is easing the burden on the shoulders of government, an economic bonus that saved the government millions over the past decades and the previous century.

Most South Africans experienced all of this with mixed feelings. The fact that the laws were backed by the official Afrikaner churches made most Afrikaners blind to the fact that most of them did not comply with fundamental biblical teachings. Most of those who did feel that things were not right, failed to act because of the measure of control the churches had on the people: If you abandon the church, you cut yourself from the Afrikaner nation and if you distance yourself from the Afrikaners, you are a deserter of your faith, culture and history (Meyer 1940:75). The 'order' that was imposed upon society was seen as a familiar blanket by the Afrikaner Christians. Unfortunately, for a large number of Afrikaners, this blanket became a substitute for their faith. They no longer had to guard their Christian identity by living and practising their faith it was taken from their hands and enforced on their behalves by the government and the church. Afrikaner Christian faith was no longer the responsibility of individuals, suffering under foreign imperial powers. The main characteristic of an empire, namely the ability to control people, was implemented by both the government and the Afrikaner churches to ensure that the concentration of power were in their hands.

\section{CONCLUSION}

The fact that politics and religion walked hand-in-hand throughout Afrikaner history, made it possible to use the political theory on empire by Colas to show how space, culture, and market were used to expand the Afrikaner Empire with the aid of the hierarchical structure that existed within the Afrikaner churches and imprinting the 'Christian order' onto day-to-day living. 
Although 80 per cent of the South African population claim to be Christians, this statistic does not paint the true picture of the functioning of religion in the country. Contrary to expectation, the Christian religion is no longer grounded in the personal conviction and behaviour of the people as it used to be during the years when the Afrikaners were fighting for their identity under the DEIC and the British Empire.

The moment that the Afrikaners gained political control, they implemented their own empire, using the same dimensions and focus areas to enhance their power and control over the country and its people. Colas states that empires control people. The Afrikaner churches supported the government's actions and they soon gain control over the Afrikaner population. They shared the government's power and control by ensuring that laws were passed to shape and discipline society to conform to Christian values and laws. This resulted in a society where everyone knew about Christian values and moral norms. Soon it became the responsibility of the government and the churches to see to it that these were adhere to. Individual commitment to faith, that to a large extent was both the founding model of the Afrikaner nation and the protection of their identity, began to fade. The Afrikaners' day-to-day practices and customs were no longer based upon personal religious values and commitment. Christianity, for most people, became a mere label (cf. Froise 2004:7, 8).

It cannot be denied that we are reaping the fruit of an historical harvest. The inability of Christians to act according to their faith and to have an impact on society, is the result of the churches taking control out of the hands of individuals (thinking and acting on behalf of people and in the process reducing them to puppets or 'children' who cannot think and act for themselves), according to the examples that history provided. This brought Afrikaner Christianity in South Africa to its knees, bowing to the worldly hunger for power and control while losing its voice and sense of right and wrong and the strong will to act as followers of Christ, regardless of the way the official church reacted to it. In the hands of the official churches, religion was degraded to the same level as politics. Christianity lost its credibility and power. Individuals are no longer capable of practising even the basic principles of their faith.

Although the 2008 testimony to the authorities by the family of Dutch Reformed churches (NG Kerk 2008) concludes with a call on all fellow believers and citizens of South Africa to '[m]aintain the values and virtues found in the Word of God' no education and training programmes were provided by the churches in this regard. It seems as if the institution is unable to empower Christians to reclaim responsibility for their actions. Even Sunday services practise the marginalisation of sins and there is no appeal to live and act in all circumstances (even behind the steering wheel or when filing SARS tax returns) according to the biblical principles.

Urgent revision of Afrikaner spirituality and religion is needed to help Afrikaners to adhere to their task and calling as Christians. Christian faith can no longer be subjected to structures that focus on social order and hierarchy. Christian mission cannot be restricted within statements and official declarations by church institutions. The Afrikaans-speaking churches must admit its use of these tools of control provided by the empire and actively sought ways to effectively part with them. Christian Afrikaners need to learn from mistakes made in the past and acknowledge the strangleholds that are inherited. Only then it will be possible to make adjustments and use the past as a compass to guide away from dangerous areas onto new paths. By reclaiming responsibility and power from the church as an institution that lost both its religious and political power, Christians will enable themselves to once again become influential and powerful, a changing force in society.

\section{REFERENCES}

Akenson, D.H., 1992, God's peoples, covenant and land in South Africa, Israel and Ulster, Cornell University Press, New York.

ANC, 1996, Nkosi, viewed 28 September 2006, from http:// www.anc.org.za/misc/nkosi.html\#hist

Assabi, A.E., 1991, 'The role of religion in the reconstruction of society 1', in W.S. Vorster (ed.), Building a new nation: The quest for a new South Africa, pp. 76-82, University of South Africa, Pretoria, South Africa.

Bryce, J., 1900, Impressions of South Africa, Macmillan, New York.

Calpin, G.H., 1944, There are no South Africans, Nelson, London.

Cameron, C., 2007, Berkouwer and the experiential theology of early Dutch Calvinism. Christ in all the Scripture/The theology of GC Berkouwer, viewed 05 May 2008, from http://www. charlescameron.wordpress.com

Camp, S.T., 1994, 'Why have you been silent? The church and the abortion ban in South Africa', Columbia Journal of Gender and Law 4(2), 143-172.

Census, 2001, Religion, viewed 04 August 2006, from http:// www.statssa.gov.za/extract.htm

Coetzee, A., 1945, 'Die Afrikaner se volkskunde [Afrikaner folklore]', in C.M. Van Den Heever, P. de V. Pienaar (eds.), 1950, Kultuurgeskiedenis van die Afrikaner: Dieeerste beskrywing van die boerevolkslewe in al sy vertakkinge, 1945-1950, deel 1, pp. 361-428, Nasionale Pers, Kaapstad.

Colas, A., 2007, Empire. Key concepts, Polity, Cambridge.

Compier, D.H., 2007, 'Jean Calvin', in K. Pui-Lan, D.H. Compier \& J. Rieger (eds.), Empire and the Christian tradition. New readings of classical theologians, pp. 215-227, Fortress Press, Minneapolis.

Conradi, E.M., 2005, 'Towards an ecological reformulation of the Christian doctrine of sin', Journal of Theology for Southern Africa 122(July), 4-22.

Cross, M., 1999, Imagery of identity in S.A. education, 1880-1990, Carolina Academic Press, Durham.

De Kiewiet, C.W., 1941, A history of South Africa: Social and economic, Oxford University Press, London.

Dreyer, P.S., 1977, "n Tipering van Afrikanerskap [Typical Afrikaner characteristics]', in P.G. Nel (ed.) Die kultuurontplooiing van die Afrikaner, pp. 37-47, HAUM, Pretoria.

Froise, M., 2004, 'Is Christianity in South Africa a label or a spiritual and ethical value system? A study of Christian adherence in the city of Welkom', MA dissertation, University of South Africa.

Froude, J.A., 1886, Oceana or England and her colonies, Longmans, London.

Gerstner, J.N., 1991, The thousand generation covenant. Dutch Reformed covenant theology and group identity in colonial South Africa, 1652-1814, Brill, Leiden.

Geyser, A., 1980, 'The place of the Bible in religious education', Journal of Theology for Southern Africa 33, 1623.

Giliomee, H., 2003, The Afrikaners: Biography of a people, Tafelberg, Cape Town.

Grenz, S.J., Guretzki, D. \& Nordling, C.F., 1999, Pocket dictionary of theological terms, InterVarsity Press, Downers Cove.

Hofmeyr, H.J., 1913, Union of South Africa: Report of the Sunday Observance Commission appointed under government notice no. 1345 of 1911, Cape Times, Cape Town.

Hofmeyr, J.W., 1991, 'Some of the fruits of the Second Reformation in the Netherlands, South Africa and North America', Journal of Theology for Southern Africa 76, 7882.

Jenkins, E., 2004, Symbols of nationhood. Presidential address: 18 November 2003, Auden House Johannesburg, South African Institute of Race Relations, Johannesburg. 
Jooste, J.P., 1946, Die verhouding tussen kerk en staat aan die Kaap tot die helfte van die negentiende eeu [The relationship between church and state at the Cape until the middle of the nineteenth century], SACUM, Bloemfontein.

Jordaan, A.M., 2004, 'Mites rondom Afrikaans [Myths about Afrikaans]', MA proefskrif, Departement Afrikaans, Universiteit van Pretoria.

Lambert, D. \& Lester, A. (eds.), 2006, Colonial lives across the British Empire. Imperial careering in the long nineteenth century, Cambridge University Press, Cambridge.

Le May, G.H.L., 1995, The Afrikaners, Blackwell, Oxford.

Meyer, P.J., 1940, Die Afrikaner, Nasionale Pers, Bloemfontein.

Moodie, J.W.D., 1835, Ten years in South Africa: Including a particular description of the wild sports of that country, Bentley, London.

Nationmaster Statistics, 2009, viewed 31 March 2009, from http://www.nationmaster.com/graph

Nel, F., 2002, Totsiens mossies [Goodbye sparrows], viewed 28 September 2006, from http://www.god-forum.co.za/ kontreiafrikaans/-mossies.htm

Nelson-Pallmeyer, J., 2005, Saving Christianity from Empire, Continuum, New York.

NG Kerk report, 1976, Human relations and the South African scene in the light of Scripture, NG Kerk Uitgewers, Cape Town.

NG Kerk, 2006, Barmhartigheidsdienste [Charity work], viewed 21 January 2008, from http://www.ngk.org.za

NG Kerk, 2008, A testimony to the authorities, viewed 21 February 2010, from http://www.ngk.org.za

O'Kulis, 1918., Doppers, Nasionale Pers, Bloemfontein.

Oliver, E., 2005, 'The impact of Christian education on the Zuid-Afrikaansche Republiek' DTh thesis, Department of Christian Spirituality, Church History and Missiology University of South Africa.

Oliver, E., 2008, 'Die invloed van die Christelike geloof op die Suid-Afrikaanse samelewing [The influence of Christian faith on the South African society]', In die Skriflig 42(2), 305326.

Pama, C., 1960, Simbole van die Unie [Symbols of the Union], Maskew Miller, Kaapstad.

Patterson, S., 1957, The last trek: A study of the Boer people and the Afrikaner nation, Routledge, London.

Pillay, G.J., 1991, In quest of a nation: Some historical pitfalls and stumbling blocks', in W.S. Vorster (ed.), Building a new nation: The quest for a new South Africa, pp. 1-14, University of South Africa, Pretoria.

Pont, A.D., 1968, $n$ Oorsig van die algemene kerkgeskiedenis en die geskiedenis van die Nederduitsch Hervormde Kerk van Afrika [An overview of the general church history and the history of the Netherdutch Reformed Church of Africa], HAUM, Pretoria.

Pont, A.D., 1970, 'Nederduitsch Hervormde Kerk van Afrika. Kerkgeskiedenis [The Netherdutch Reformed Church of Africa. Church history]', HAUM, Pretoria.
Preston, A., 1989, Suid-Afrikaanse geskiedenis in beeld [South African history in pictures], Bison, Londen.

Pretorius, E., 2008, Moerdijk en die gedagte van die altar [Moerdijk and the concept of the alter], Voortrekker Monument, Pretoria.

Pui-Lan, K., Compier, D.H. \& Rieger, J., (eds.), 2007, Empire and the Christian tradition. New readings of classical theologians, Fortress Press, Minneapolis.

Richardson, N., 2001, 'Apartheid, heresy and the church in South Africa', The Journal of Religious Ethics 14(1), 1-21.

Rieger, J., 2007, 'Christian Theology and Empires', in K. PuiLan, D.H. Compier \& J. Rieger (eds.), Empire and the Christian tradition. New readings of classical theologians, pp. 1-13, Fortress Press, Minneapolis.

Rose, E.B., 1902, 'The truth about the Transvaal: A record of facts based upon twelve years residence in the country', Rose, London.

Schutte, J.H.T., 1943, 'Die kulturele eenwording van die Boere in die Republieke, 1854-1877 [The cultural unification of the Boers in the Republics, 1854-1877]', MA proefskrif, Universiteit van Pretoria.

Sooka, Y.L., 1993, 'A Hindu experience of religious freedom in the South African context', in J. Kilian (ed.), Religious freedom in South Africa, pp. 82-92, University of South Africa, Pretoria, South Africa.

South Africa, 1950, House of assembly. Debates, Government Printer, Pretoria, South Africa.

Statistics South Africa, 2004, Statistics South Africa, viewed 03 July 2006, from http://www.statssa.gov.za

Stuart, J., 1854, De Hollandsche Afrikanen en hunne republieken in Zuid-Afrika [The Dutch Africans and their republics in South Africa], Tielkemeijer, Amsterdam.

Swaraj Foundation, 2001, The counter renaissance: A publication by and for African youth, viewed 05 March 2008, from http:// www.swaraj.org/counterrenmay.htm

Symington, J. (ed.), 2005, South African Christian handbook 2005/2006, Lux Verbi, Cape Town.

Van der Kooi, P., 1999, 'Die ware betekenis van die calvinisme [The true meaning of Calvinism]', Die Kerkpad 3(4), 1, viewed 05 March 2008, from http://Home.mweb.co.za/ke/ kerkpad/julie99-/calvinisme-.html

Van Wyk, J.H., 1980, Die etiek van kans: 'n Teologies-etiese besinning oor veral dobbelary, lotery en kansspeletjies [The ethics of risk: A theological-ethical reflection on particular gambling, lottery and games of chance], Wetenskaplike bydraes van die Potchefstroomse Universiteit vir Christelike Hoër Onderwys (nou Noordwes-Universiteit): Reeks F1, IBCstudiestukke, Potchefstroom. 